\title{
Challenges of NK cell-based immunotherapy in the new era
}

\author{
Fang Fang, Weihua Xiao (凶), Zhigang Tian (ه)
}

Institute of Immunology and the CAS Key Laboratory of Innate Immunity and Chronic Disease, Innovation Center for Cell Signaling Network, School of Life Sciences and Medical Center, University of Science and Technology of China, Hefei 230027, China; Hefei National Laboratory for Physical Sciences at Microscale, Hefei 230027, China

(C) The Author(s) 2018. This article is published with open access at link.springer.com and journal.hep.com.cn 2018

\begin{abstract}
Natural killer cells (NKs) have a great potential for cancer immunotherapy because they can rapidly and directly kill transformed cells in the absence of antigen presensitization. Various cellular sources, including peripheral blood mononuclear cells (PBMCs), stem cells, and NK cell lines, have been used for producing NK cells. In particular, NK cells that expanded from allogeneic PBMCs exhibit better efficacy than those that did not. However, considering the safety, activities, and reliability of the cell products, researchers must develop an optimal protocol for producing NK cells from PBMCs in the manufacture setting and clinical therapeutic regimen. In this review, the challenges on NK cell-based therapeutic approaches and clinical outcomes are discussed.
\end{abstract}

Keywords natural killer cells; immunotherapy; adoptive transfer; genetic modification; immune checkpoint inhibitor

\section{Introduction}

Natural killer (NK) cells are the direct killers of tumor cells $[1,2]$. NK cells recognize target cells through two classes of receptors: killer immunoglobulin-like receptors (KIRs) and killer activation receptors (KARs). KIRs recognize "self" molecules, pair with human leukocyte antigen (HLA) class-I molecules, and transmit inhibitory signals to maintain tolerance to NK cells. KARs pair with damageassociated proteins to recognize "abnormal" molecules on target cells and transmit activation signals. In tumor cells, HLA molecules are often reduced or absent, and damageassociated proteins are upregulated, reducing inhibitory signals through KIRs and promoting activation through KARs on NK cells [3]. Such recognition models between KIRs and HLA molecules are referred to as "missing-self" recognition, and KARs and damage-associated proteins are involved in "stress-induced" recognition [4]. Nevertheless, the triggering of the cytotoxicity of NK cells involves a balance between inhibitory and activation signals [4-6]. Activated NK cells can kill tumor cells directly by (1) secreting granules that contain perforin and granzymes and (2) ligation through Fas ligand and tumor necrosis factor-related apoptosis-inducing ligand. Moreover, acti-

Received January 31, 2018; accepted June 26, 2018

Correspondence: Weihua Xiao, xiaow@ustc.edu.cn; Zhigang Tian,tzg@ustc.edu.cn vated NK cells can secrete several cytokines and chemokines that can regulate innate and adaptive immune cells to achieve indirect cytotoxic activities (Fig. 1) $[7,8]$.

Other well-known killer cells are cytotoxic $\mathrm{T}$ lymphocytes (CTLs) and natural killer T (NKT) cells. These cells recognize target cells through their antigen-specific $\mathrm{T}$ cell receptors (TCRs) and transmit activation signals. TCRs in CTLs or NKT cells pair with specific antigens on target cells presented by major histocompatibility complex (MHC) class-I molecules [9] or CD1d molecules [10,11]. These distinct recognition and activation mechanisms between T cells and NK cells may result in diverse actions and outcomes in cancer immunotherapy.

In this review, the contribution and challenges of NK cell-based immunotherapy are discussed.

\section{Approaches of NK cell-based immunotherapy}

\section{Adoptive cell transfer (ACT)}

ACT has been extensively applied in anticancer therapy in clinical trials [12]. In NK cells, the greater the alloreactivity between donor and recipient is, the better the antitumor efficacy is [13-16]. This relationship is consistent with the mechanisms of NK-cell recognition, whereby autologous NK cells are potentially inhibited by self MHC class-I molecules on cancer cells. Based on the genotypes of KIR 


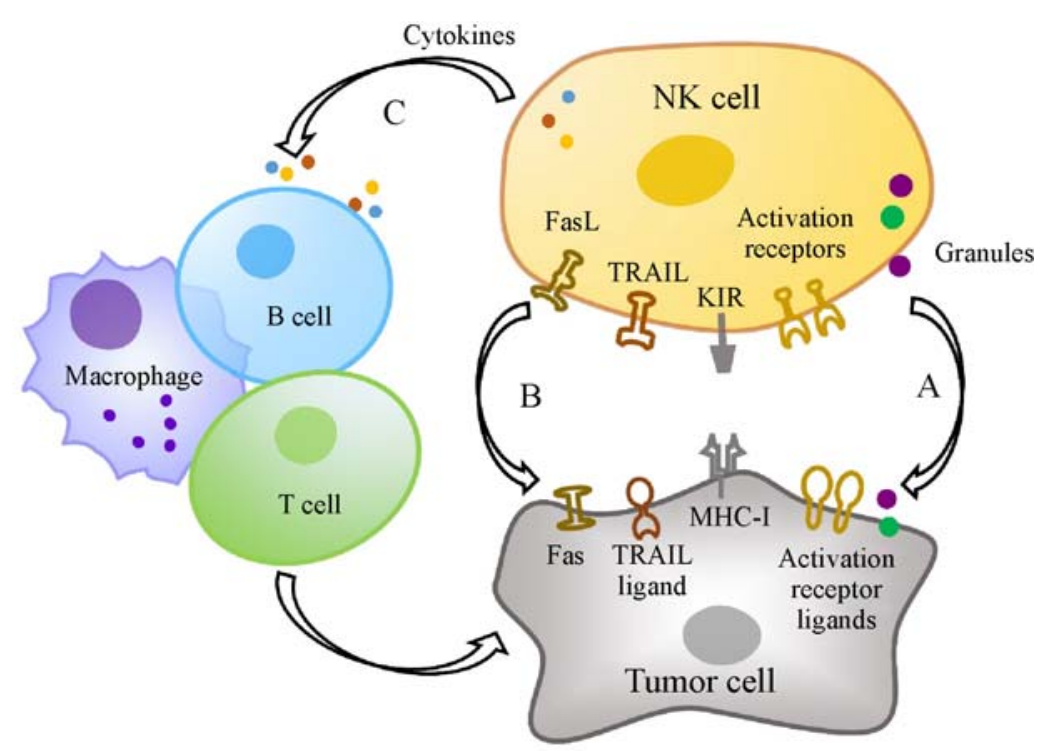

Fig. 1 Killing mechanisms of NK cell against tumor cells. Upon the formation of immunological synapse between activated NK cell and tumor cell, multiple killing mechanisms can be triggered, including direct killing of the tumor cell by the (A) release of granules containing perforin and granzymes and (B) induction of apoptosis through the ligation of Fas-FasL or TRAIL-TRAIL ligand, and indirect killing through $(\mathrm{C})$ the secretion of factors that recruit and promote the activation of other inflammatory cells that indirectly kill a target cell.

and KIR ligands from donors and recipients, five donorselection models have been developed and validated in clinical trials $[17,18]$. However, considering the feasibility and efficiency of selection of NK-cell donors, we should expand and evaluate the criteria for donor selection.

Two distinct basic protocols, with or without feeder cells, have been developed for the expansion of NK cells ex vivo. Both protocols can be used for expanding NK cells by over a thousandfold [19-22], remarkably improve NKcell expansion to a greater extent than cytokine-induced killer (CIK) protocols, and lead to a new era of NK-cell therapy $[23,24]$. However, feeder cells derived from leukemia lines (e.g., K562) present safety consideration and require further purification and additional measures for quality control (Table 1). By contrast, feeder-free protocols employ clinical-grade or US Food and Drug Administration-approved cytokines, stimuli, and antibodies with serum-free culture medium, and they can reach approximately $70 \%$ of NK cell purity from peripheral blood mononuclear cells (PBMCs) (Table 1). However, the number and purity of expanded NK cells from different donors remarkably vary, as observed in feeder-free protocols, which still need improvement. The purity and phenotype of the NK cells produced by different systems also differ $[25,26]$. These differences can directly influence the dose of the effector cells used for transfer and clinical efficacy. Overall, standardized measurements for the production and quality control of NK cells are lacking, possibly causing substantial variations in therapeutic outcomes.

Table 1 Manufacture of NK cells

\begin{tabular}{|c|c|c|c|c|c|}
\hline Starting material & Protocol features & NK cell purity & Expansion fold & Properties & References \\
\hline NK92 & Cytokine & N/A & N/A & $\begin{array}{l}\text { Additional irradiate step } \\
\text { before use }\end{array}$ & {$[81,103]$} \\
\hline CB-MNC & Allogeneic feeder cells & $72 \%-95 \%$ & $35-2389$ & - & {$[104,105]$} \\
\hline Stem cell & Cytokines and antibodies & $\geqslant 70 \%$ & $1000-2100$ & Lack in vivo "education" & {$[106-111]$} \\
\hline \multirow{2}{*}{$\begin{array}{l}\text { PBMC CD3 depleted } \\
\text { or/and CD56 enriched }\end{array}$} & Cytokine combination & $75 \%-99 \%$ & $3-131$ & \multirow{2}{*}{$\begin{array}{l}\text { Additional purification } \\
\text { step, low expansion rate }\end{array}$} & {$[79,112-115]$} \\
\hline & $\begin{array}{l}\text { Allogeneic feeder cells } \\
\text { plus cytokine or/and ant } \\
\text { body }\end{array}$ & $\geqslant 90 \%$ & $16-3637$ & & [116-120] \\
\hline \multirow[t]{2}{*}{ PBMC } & $\begin{array}{l}\text { Cytokines, antibodies, or/ } \\
\text { and other stimulators }\end{array}$ & $\geqslant 70 \%$ & $140-5712$ & \multirow[t]{2}{*}{$\begin{array}{l}\text { Simple protocols of } \\
\text { expansion, low purity }\end{array}$} & {$[19,20,121]$} \\
\hline & Feeder cells & $66 \%-99 \%$ & $20-14116$ & & {$[21,22,122,123]$} \\
\hline
\end{tabular}

CB-MNC, cord blood mononuclear cells; PBMC, peripheral blood mononuclear cell. 


\section{Genetic modification of NK cells}

Genetic modification of cells, such as chimeric antigen receptor (CAR)-NK cells and armed-NK cells, enables the specific targeting or augmented cytotoxicity of NK cells $[27,28]$. This technique has been successfully implemented in T cells. Approximately two-thirds of clinical trials are targeting hematologic malignancies involving antigens, such as CD19, CD20, CD123, CD22, and B cell maturation antigen $[29,30]$. The most frequently targeted antigen is CD19. Clinical trials with CD19-CAR-T cells have revealed an objective response rate (ORR) of $>60 \%$, and other reported complete remission (CR) rates have reached $>85 \%$ [30]. The reported side effects and toxicities include neurologic toxicity, cytokine release syndrome, tumor lysis syndrome, immunogenicity, and ontarget, off-tumor recognition [30]. To some extent, the long-lasting and production of pro-inflammatory cytokines from CAR-T cells in vivo is the cause of severe side effects [31]. NK cells have been considered better candidates for CARs because their short lifespans last for nearly 2 week in vivo and they mainly produce interferon (IFN)- $\gamma$ $[32,33]$. Moreover, CAR-NK cell activation not only depends on CARs but also is compromised by integrated signals from inhibitory and activating receptors. These multiple signals on CAR-NK cells can prevent on-target, off-tumor effects, but this system can also have unfavorable consequences. GD2-CAR-NK cells failed to eliminate GD2-expressing Ewing sarcomas in a preclinical study when a xenograft model is used mainly because GD2-CAR cells upregulate immunosuppressive ligand HLA-G in cancer cells. HLA-G interact with KIR on NK cells and transduce inhibitory signals [34]. CAR-NK cells targeting well-known targets, such as CD19, CD20, SLAMP7, and EpCAM, have been tested in vivo with in-mouse models or in vitro. However, only few of these targets have proceeded to clinical trials, including CD19-CAR-NK cells and CD33-CAR-NK cells (NCT0194479, NCT00995137), and the results have not yet been reported [35]. Appropriate design of the CAR structure and transfection of the expression vectors into NK cells are challenging steps in the development of CAR-NK cells. These steps will be discussed in detail in the section, "Challenges in NK cell immunotherapy."

\section{Checkpoint inhibitor}

Checkpoint inhibitors targeting inhibitory receptors can augment immune-cell function, thereby effectively suppressing tumor cells [36-38]. Inhibitory KIRs expressed in NK cells play key roles in maintaining tolerance to NK cells. The KIR-blocking antibody IPH2101 is under a phase-II clinical trial for multiple myeloma treatment but responded minimally in preliminary trials possibly due to the trogocytosis of KIR2DL1/L2/L3 molecules from the surface of NK cells by neutrophils and eosinophils induced by IPH2101. This effect may be reversed by optimizing the clinical scheme and combination therapy [39]. Furthermore, several blocking antibodies, such as the antiNKG2A blocking antibody monalizumab and the antiTim-3 blocking antibody MBG453 [40-42], target immune checkpoints on NK and T cells and can reverse NK-cell dysfunction in preclinical studies. However, the safety and efficacy of these inhibitors or combination therapies require further investigation.

\section{Cytokines and immunomodulatory drugs}

Several cytokines and immunomodulatory drugs, such as the common $\gamma$-chain family of cytokines (interleukin (IL)2, IL-7, IL-15, and IL-21), thalidomide, and pomalidomide, boost NK-cell cytotoxicity $[43,44]$. However, the targets of these cytokines and drugs vary [45]. Optimizing and improving the side effects of these modulatory factors are the key steps toward their clinical application $[46,47]$.

\section{Contribution of NK cells to cellular immunotherapy}

Several cell types, including antigen-sensitized dendritic cells (DC), tumor-infiltrating lymphocytes (TIL), CIK cells, and NK cells, have been used for ACT immunotherapy [48-50]. Immunotherapy using NK cells is a panspecific ACT immunotherapy that does not rely on the recognition of HLA-mediated tumor antigen [51]. Autologous and allogeneic NK cells can be both used in ACT immunotherapy because their safety and tolerability have been proven [52-54]. Indeed, allogeneic NK cells exhibit better anti-tumor efficacy than autologous NK cells $[15,16,55]$. Various sources of $\mathrm{NK}$ cells, including peripheral blood-derived NK (PBNK) cells, CD34 ${ }^{+}$stem cell-derived NK cells, and NK cell lines, such as NK-92, have been used for ACT immunotherapy [56]. PBNK cells are the most widely used in clinical trials because they are safe, can be collected conveniently, and can strongly kill tumor cells. However, because of the low number of PBNK cells in blood, they require to be expanded ex vivo. Unlike $\mathrm{T}$ cells, donor NK cells last approximately 2-3 weeks in vivo $[57,58]$. The short lifespan of NK cells reduces the risk of unpredictable long-term side effects. Moreover, NK cell transfer cannot cause serious or uncontrollable graft-versus-host disease (GVHD) or toxicity $[12,59,60]$. NK cells have been used for treating hematopoietic malignancies (e.g., leukemia, lymphoma, and multiple myeloma) and solid tumors (e.g., melanoma, ovarian cancer, lung cancer, colorectal cancer, and glioblastoma) [53,61] (Table 2). 
Table 2 Clinical outcome of NK cell-based immunotherapy

\begin{tabular}{llll}
\hline Source of NK cells & Patient characteristic & Clinical outcome & References \\
\hline NK-92 & Solid tumor $(n=31)$ & $\mathrm{CR}=0, \mathrm{PR}=4 / 31, \mathrm{SD}=5 / 31$ & {$[81,124,125]$} \\
& Lymphoma $(n=3)$ & $\mathrm{CR}=1 / 3, \mathrm{PR}=1 / 3, \mathrm{SD}=0$ & {$[81,124]$} \\
& Hematopoietic malignancy $(n=12)$ & $\mathrm{CR}=1 / 12, \mathrm{PR}=1 / 12, \mathrm{SD}=2 / 12$ & {$[103,124]$} \\
CD34 ${ }^{+}$cell-derived NK cells & Hematopoietic malignancy, reached CR & $\mathrm{DFS} \geqslant 12$ months, 1-year OS 11/15, & {$[62,73,126]$} \\
& in previous therapy $(n=18)$ & 2 -year OS $4 / 15$ & \\
& Hematopoietic malignancy $(\mathrm{NK}$ cell & $\mathrm{CR}=9 / 20, \mathrm{PR}=9 / 20, \mathrm{SD}=0$ & {$[73,126]$} \\
& combination therapy) $(n=20)$ & & \\
Autologous PBNK & Solid tumor $(n=36)$ & $\mathrm{CR}=0, \mathrm{PR}=1 / 36, \mathrm{SD}=10 / 36$ & {$[122,127,128]$} \\
& Hematopoietic malignancy $(n=9)$ & $\mathrm{CR}=0, \mathrm{PR}=2 / 9, \mathrm{SD}=3 / 9$ & {$[129,130]$} \\
Allogeneic PBNK & Solid tumor $(n=58)$ & $\mathrm{CR}=0, \mathrm{PR}=12 / 58, \mathrm{SD}=31 / 58$ & {$[78,79,128,131]$} \\
& Lymphoma $(n=6)$ & $\mathrm{CR}=2 / 6, \mathrm{PR}=2 / 6, \mathrm{SD}=0$ & {$[55]$} \\
& Hematopoietic malignancy, reached CR & $\mathrm{DFS} \geqslant 18$ months, 1-year OS 13/16, & {$[63,64]$} \\
& in previous therapy $(n=16)$ & $2-\mathrm{year}$ OS $12 / 16$ & {$[58,64,132]$} \\
\hline
\end{tabular}

PBNK, peripheral blood mononuclear cell-derived NK cells; CR, complete remission; PR, partial remission; SD, stable disease; DFS, disease-free survival; OS, overall survival.

\section{Hematopoietic malignancies}

Infusion of NK cells for hematopoietic malignancy treatment is used in two settings: stem-cell transplantation (SCT) and non-SCT.

Allogenic NK cells control hematopoietic malignancies effectively because of the graft-versus-leukemia effect. In patients who have reached $\mathrm{CR}$ or morphologic $\mathrm{CR}$, adoptive NK cell transfer can remarkably prolong disease-free progression. Of the 28 patients reported, 4 had CR lasting for about 1 year, 5 had CR lasting for about 1.5 years, and 10 had CR lasting for about 2 years [62-64]. Meanwhile, 24 out of 50 patients with active diseases reached CR [55, 58, 65-67]. In patients with relapsed or refractory acute myeloid leukemia (AML), the mean CR rate was approximately $40 \%$, which was considerably higher than that obtained by conventional chemotherapy (10\%) [53] (Table 2). Overall, such clinical trials demonstrated that allogeneic NK cell adoptive transfer, as immunotherapy for hematopoietic malignancies (especially AML), is efficacious and safe without severe GVHD or side effects.

NK cell adoptive transfer has been used extensively in combination with SCT for hematopoietic malignancies. $\mathrm{SCT}$, combined with NK cells, improves two-year overall survival (OS) to $36 \%$ and reduces the risk of relapse, compared with SCT alone, which achieves a two-year OS of $15 \%$ [68-70]. The sequence of SCT and infusion of NK cells influence clinical outcomes. NK cell infusion performed before or within 2 weeks after SCT has a better clinical outcome than that performed 4 weeks after SCT [68-74], suggesting that NK cells contribute to the control of tumor metastasis, minimal residual disease, and tumor stem cells. Nevertheless, the optimal clinical procedures, including timing, frequency, and dose of NK-cell infusion, may need more extensive studies.

Compared with NK cells, CIK cells are less effective against hematopoietic malignancies. Patients with hematopoietic malignancies receiving CIK treatments, the ORR was $30 \%$ (60/203), however the ORR was $58 \%$ with NKcell treatment (Table 2) [75]. The reason for the low efficacy of CIK cells could be because $>70 \%$ of the CIK cells are $\mathrm{T}$ cells (mainly naive $\mathrm{T}$ cell). In addition, tumorassociated antigen-specific T cells, especially CAR-T cells, have become the central player and recently demonstrated exciting results against hematopoietic malignancies.

Although NK cell immunotherapy has demonstrated substantial clinical benefit against hematopoietic malignancies, the relapse rate still needs to be improved. NK cell therapy can be potentially used for combination therapy.

\section{Solid tumors}

NK cells have innate advantages in the treatment of certain solid tumors, such as melanoma and ovarian cancer. More than half of melanomas in situ have reduced or absent HLA expression, which is required in the mediation of $\mathrm{CD} 8^{+} \mathrm{T}$ cell recognition [76] but not in NK cells recognition. Therefore, NK cell therapy is an effective approach against these cancers. Moreover, IFN- $\gamma$ is the major cytokine secreted by NK cells and has been shown to induce the permanent arrest of the growth of melanoma cells [77]. Ovarian cancer cells have high expression of MICA/B and ULBPs, which can activate NK cells through the active receptor NKG2D [51]. However, immunotherapies, which use NK cells for melanoma, ovarian cancer, and other solid tumors, can control disease progression but limitedly improve or abate disease [76,78-83]. The possible reasons 
include (1) low infiltration rate of NK cells to the solid tumor; (2) inhibitory factors, such as transforming growth factor- $\beta$, in the tumor microenvironment; and (3) inhibition from tumor cells, such as residual HLA expression. Potential solutions for these crucial issues have been proposed, including enhancing the migration of NK cells to tumor sites, altering the tumor microenvironment through gene modification or clearance of immunosuppressive cells, and combining with a checkpoint inhibitor to activate NK cells. Recent studies have shown that IFN- $\gamma$ can drive the fragility of T-regulatory cells to promote antitumor immunity, suggesting that NK cells, as an important source of IFN- $\gamma$, may substantially contribute for the immunotherapy of solid tumors [84].

\section{Cancer stem cells (CSCs)}

CSCs, which have low proliferation rate and asymmetrical growth, are resistant to conventional tumor therapy. The low expression of MHC class-I molecules, which mediate the recognition of $\mathrm{CD}^{+} \mathrm{T}$ cells to target cells, predicts the low cytolytic efficiency of CD8 ${ }^{+} \mathrm{T}$ cells to CSCs [85]. NK cells, which can kill "self-missing" tumor cells, preferentially target CSCs derived from colon tumors, melanomas, glioblastomas, pancreatic tumors, and breast tumors [85]. Furthermore, NK cells also play a key role in suppressing tumor metastasis formation with possible preferential targeting of CSCs [86,87]. Indeed, NK-cell therapy remarkably prolongs disease-free progression in hematopoietic malignancies [55,58,65-67], suggesting that NK cells may contribute in controlling the metastasis and recurrence of tumor cells by targeting CSCs preferentially. However, NK cells need further investigation and more evidence on their control of CSCs.

\section{Combination therapy}

Several studies have tested the combination of NK cells with traditional therapy and/or immunotherapy to improve clinical outcomes. Two strategies have been proposed.

First is the reduction of tumor burden and disruption of tumor stroma, thereby enhancing tumor cell sensitivity. Radiotherapy can upregulate the expression of stressrelated ligands on tumor cells, thereby increasing their sensitivity to NK cells. Local radiation combined with NK cell adoptive transfer can remarkably prolong the survival of tumor-bearing mice [88]. An undergoing study have moved forward to phase-II clinical trials for the assessment of the effects of radiochemotherapy with NK cells on patients with non-small-cell lung cancer [89]. Several clinical trials combining NK cells and chemotherapy for solid tumor treatment are underway [61,90,91]. Chemotherapy has been shown to promote the sensitivity of tumor cells to NK cells and deplete immune cells to make room for infused NK cells $[92,93]$.
Second is the enhancement of cytolytic ability or tumorcell targeting of NK cells. Federico et al. used anti-GD2 monoclonal antibody combined with chemotherapy and transferred haploidentical NK cells to treat recurrent or refractory neuroblastoma, resulting in a promising antitumor activity. Out of 11 patients, four had a CR, one had an excellent partial response, and three had a partial response; the one-year OS was 77\%, and the median time to progression was 274 days [94]. Moreover, checkpoint inhibitors, such as the antibodies anti-KIR [95], antiCD137 [96], and anti-TIGIT [97], have been exploited for the augmentation of NK cell functions. Bi- or tri-specific killer engagers that can enhance the targeting of NK cells to tumor cells and augment the cytotoxicity of NK cells have been intensively studied $[98,99]$. However, the outcomes of these combination therapies are diverse, and the role of these accelerants in combination with NK-cell therapy remains to be validated clinically $[61,78,90,91]$. These phenomena are probably caused by poor persistency and proliferation of NK cells in vivo. These conditions are expected to be improved by ex vivo activation and optimization of therapy regimen (e.g., dose, intensity, and the sequential order of the different treatments).

\section{Challenges in NK cell immunotherapy}

Preclinical and early clinical trials with NK-cell immunotherapies exhibit safety and encouraging clinical outcomes against hematologic malignancies. However, only a few of early-stage clinical trials on solid tumors have not reached any conclusion (Table 2). More studies on solid tumors are needed for the exploration of tumor types sensitive to NK cell immunotherapy.

Various cell types have been developed for NK cell generation for immunotherapy, including induced pluripotent stem cells, cord blood, peripheral blood NK cells, and NK-92 line. Although each cell type exerts some unique features, the potent cytotoxic response against different types of tumors remains to be elucidated. Moreover, developing off-the-shelf and strong cytotoxic NK cells is necessary in clinical applications.

$\mathrm{NK}$ and $\mathrm{T}$ cells use distinct tumor cell recognition mechanisms. They can be sensitive or synergistic to different tumor types. So, the clinical outcome of combination therapy with $\mathrm{NK}$ and $\mathrm{T}$ cells or other tumor therapy strategies need to be confirmed with large-scale clinical trials.

Allogenic NK cells from peripheral blood are safe and satisfactorily effective against tumors. Meanwhile, variations across individual donors for in vitro NK cell expansion rate and cytotoxicity are observed. Although predicted donor selection models, considering KIR-MHC I mismatches, has been proposed [17], and biomarkers influencing other NK cell properties and cytotoxicity, such 
as matrices of KARs and KIRs, in both donor and recipient remain to be further elucidated.

CAR expression enables carrier cells to recognize antigens on tumor-cell surfaces without MHC restriction. Transfection efficiency for primary NK cells particularly remains the bottleneck. The transduction efficiency can reach approximately $70 \%$ in retroviruses in T cells [29], $15 \%-40 \%$ in NK cell lines [100], less than $20 \%$ in primary NK cells, and 6\%-96\% in ex vivo expanded NK cells [101]. Transiently inhibiting the antiviral defense signaling pathway leads to remarkably increased virus transduction efficiency, but it is not practical for the large-scale manufacture of CAR-NK cells [102]. Electroporation can substantially increase the transfection efficiency, but transient expression limits its CAR expression when the cell proliferated in vivo [101]. In summary, an efficient, reliable, and convenient transfection protocol is the bottleneck for developing gene-modified NK cells.

\section{Conclusions}

NK cells, as the only innate immune cells in lymphocytes, have unique advantages for tumor immunotherapy. The challenges in both optimized clinical schemes and techniques of NK cell generation remain to be developed. Optimal combinations with NK cells and other therapeutic methods, including $\mathrm{T}$ cell therapy could be synergistic to tumor immunotherapy.

\section{Acknowledgements}

This work was supported by the National Natural Science Foundation of China (Nos. 81788101, 91542000, 81671558, and 31571440); the Ministry of Science and Technology of China (No. 2016YFC1303503) and Chinese Academy of Sciences (Nos. XDA12020312, XDPB030301, and XDPB030303).

\section{Compliance with ethics guidelines}

Fang Fang, Weihua Xiao, and Zhigang Tian declare that they have no conflict of interest. This manuscript is a review article and does not involve a research protocol requiring approval by the relevant institutional review board or ethics committee.

Open Access This article is distributed under the terms of the Creative Commons Attribution 4.0 International License (http:// creativecommons.org/licenses/by/4.0/), which permits unrestricted use, distribution, and reproduction in any medium, provided the appropriate credit is given to the original author(s) and the source, and a link is provided to the Creative Commons license, which indicates if changes are made.

\section{References}

1. Herberman RB, Nunn ME, Lavrin DH. Natural cytotoxic reactivity of mouse lymphoid cells against syngeneic acid allogeneic tumors. I. Distribution of reactivity and specificity. Int J Cancer 1975; 16 (2): 216-229

2. Kiessling R, Klein E, Pross H, Wigzell H. "Natural" killer cells in the mouse. II. Cytotoxic cells with specificity for mouse Moloney leukemia cells. Characteristics of the killer cell. Eur J Immunol 1975; 5(2): 117-121

3. Béziat V, Hilton HG, Norman PJ, Traherne JA. Deciphering the killer-cell immunoglobulin-like receptor system at super-resolution for natural killer and T-cell biology. Immunology 2017; 150(3): 248-264

4. Martinet L, Smyth MJ. Balancing natural killer cell activation through paired receptors. Nat Rev Immunol 2015; 15(4): 243-254

5. Chester C, Fritsch K, Kohrt HE. Natural killer cell immunomodulation: targeting activating, inhibitory, and co-stimulatory receptor signaling for cancer immunotherapy. Front Immunol 2015; 6: 601

6. He Y, Tian Z. NK cell education via nonclassical MHC and nonMHC ligands. Cell Mol Immunol 2017; 14(4): 321-330

7. Vivier E, Tomasello E, Baratin M, Walzer T, Ugolini S. Functions of natural killer cells. Nat Immunol 2008; 9(5): 503-510

8. Liu Y, Zheng J, Liu Y, Wen L, Huang L, Xiang Z, Lam KT, Lv A, Mao H, Lau YL, Tu W. Uncompromised NK cell activation is essential for virus-specific CTL activity during acute influenza virus infection. Cell Mol Immunol 2017;14: 1-11

9. Sun JC, Lanier LL. NK cell development, homeostasis and function: parallels with $\mathrm{CD}^{+} \mathrm{T}$ cells. Nat Rev Immunol 2011; 11 (10): 645-657

10. Nair $S$, Dhodapkar MV. Natural killer $T$ cells in cancer immunotherapy. Front Immunol 2017; 8: 1178

11. Shissler SC, Bollino DR, Tiper IV, Bates JP, Derakhshandeh R, Webb TJ. Immunotherapeutic strategies targeting natural killer $\mathrm{T}$ cell responses in cancer. Immunogenetics 2016; 68(8): 623-638

12. Davis ZB, Felices M, Verneris MR, Miller JS. Natural killer cell adoptive transfer therapy: exploiting the first line of defense against cancer. Cancer J 2015; 21(6): 486-491

13. Zhang QF, Yin WW, Xia Y, Yi YY, He QF, Wang X, Ren H, Zhang DZ. Liver-infiltrating CD11b ${ }^{-C D} 27^{-}$NK subsets account for NK-cell dysfunction in patients with hepatocellular carcinoma and are associated with tumor progression. Cell Mol Immunol 2017; 14(10): 819-829

14. Krneta T, Gillgrass A, Chew M, Ashkar AA. The breast tumor microenvironment alters the phenotype and function of natural killer cells. Cell Mol Immunol 2016; 13(5): 628-639

15. Lim O, Jung MY, Hwang YK, Shin EC. Present and future of allogeneic natural killer cell therapy. Front Immunol 2015; 6: 286

16. Morvan M, David G, Sébille V, Perrin A, Gagne K, Willem C, Kerdudou N, Denis L, Clémenceau B, Folléa G, Bignon JD, Retière C. Autologous and allogeneic HLA KIR ligand environments and activating KIR control KIR NK-cell functions. Eur J Immunol 2008; 38(12): 3474-3486

17. Wang W, Erbe AK, DeSantes KB, Sondel PM. Donor selection for ex vivo-expanded natural killer cells as adoptive cancer immu- 
notherapy. Future Oncol 2017; 13(12): 1043-1047

18. Koehl U, Kalberer C, Spanholtz J, Lee DA, Miller JS, Cooley S, Lowdell M, Uharek L, Klingemann H, Curti A, Leung W, Alici E. Advances in clinical NK cell studies: donor selection, manufacturing and quality control. OncoImmunology 2016; 5(4): e1115178

19. Deng X, Terunuma H, Nieda M, Xiao W, Nicol A. Synergistic cytotoxicity of ex vivo expanded natural killer cells in combination with monoclonal antibody drugs against cancer cells. Int Immunopharmacol 2012; 14(4): 593-605

20. Li X, He C, Liu C, Ma J, Ma P, Cui H, Tao H, Gao B. Expansion of NK cells from PBMCs using immobilized 4-1BBL and interleukin-21. Int J Oncol 2015; 47(1): 335-342

21. Denman CJ, Senyukov VV, Somanchi SS, Phatarpekar PV, Kopp LM, Johnson JL, Singh H, Hurton L, Maiti SN, Huls MH, Champlin RE, Cooper LJ, Lee DA. Membrane-bound IL-21 promotes sustained ex vivo proliferation of human natural killer cells. PLoS One 2012; 7(1): e30264

22. Garg TK, Szmania SM, Khan JA, Hoering A, Malbrough PA, Moreno-Bost A, Greenway AD, Lingo JD, Li X, Yaccoby S, Suva LJ, Storrie B, Tricot G, Campana D, Shaughnessy JD Jr, Nair BP, Bellamy WT, Epstein J, Barlogie B, van Rhee F. Highly activated and expanded natural killer cells for multiple myeloma immunotherapy. Haematologica 2012; 97(9): 1348-1356

23. Schmidt-Wolf IGH, Lefterova P, Johnston V, Huhn D, Blume KG, Negrin RS. Propagation of large numbers of T cells with natural killer cell markers. Br J Haematol 1994; 87(3): 453-458

24. Schmidt-Wolf GD, Negrin RS, Schmidt-Wolf IG. Activated T cells and cytokine-induced $\mathrm{CD}^{+} \mathrm{CD}^{+} 6^{+}$killer cells. Ann Hematol 1997; 74(2): 51-56

25. Granzin M, Wagner J, Köhl U, Cerwenka A, Huppert V, Ullrich E. Shaping of natural killer cell antitumor activity by ex vivo cultivation. Front Immunol 2017; 8: 458

26. Chabannon C, Mfarrej B, Guia S, Ugolini S, Devillier R, Blaise D, Vivier E, Calmels B. Manufacturing natural killer cells as medicinal products. Front Immunol 2016; 7: 504

27. Bollino D, Webb TJ. Chimeric antigen receptor-engineered natural killer and natural killer T cells for cancer immunotherapy. Transl Res 2017; 187: 32-43

28. Song X, Hong SH, Kwon WT, Bailey LM, Basse P, Bartlett DL, Kwon YT, Lee YJ. Secretory trail-armed natural killer cell-based therapy: in vitro and in vivo colorectal peritoneal carcinomatosis xenograft. Mol Cancer Ther 2016; 15(7): 1591-1601

29. Piscopo NJ, Mueller KP, Das A, Hematti P, Murphy WL, Palecek SP, Capitini CM, Saha K. Bioengineering solutions for manufacturing challenges in CAR T cells. Biotechnol J 2018; 13(2): 1700095

30. Hartmann J, Schüßler-Lenz M, Bondanza A, Buchholz CJ. Clinical development of CAR $\mathrm{T}$ cells-challenges and opportunities in translating innovative treatment concepts. EMBO Mol Med 2017; 9(9): 1183-1197

31. Ritchie DS, Neeson PJ, Khot A, Peinert S, Tai T, Tainton K, Chen K, Shin M, Wall DM, Hönemann D, Gambell P, Westerman DA, Haurat J, Westwood JA, Scott AM, Kravets L, Dickinson M, Trapani JA, Smyth MJ, Darcy PK, Kershaw MH, Prince HM. Persistence and efficacy of second generation CAR T cell against the LeY antigen in acute myeloid leukemia. Mol Ther 2013; 21 (11): 2122-2129
32. Casucci M, Perna SK, Falcone L, Camisa B, Magnani Z, Bernardi M, Crotta A, Tresoldi C, Fleischhauer K, Ponzoni M, Gregori S, Caligaris Cappio F, Ciceri F, Bordignon C, Cignetti A, Bondanza A, Bonini C. Graft-versus-leukemia effect of HLA-haploidentical central-memory T-cells expanded with leukemic APCs and modified with a suicide gene. Mol Ther 2013; 21(2): 466-475

33. Leboeuf C, Mailly L, Wu T, Bour G, Durand S, Brignon N, Ferrand $\mathrm{C}$, Borg C, Tiberghien $\mathrm{P}$, Thimme R, Pessaux $\mathrm{P}$, Marescaux J, Baumert TF, Robinet E. In vivo proof of concept of adoptive immunotherapy for hepatocellular carcinoma using allogeneic suicide gene-modified killer cells. Mol Ther 2014; 22 (3): 634-644

34. Kailayangiri S, Altvater B, Spurny C, Jamitzky S, Schelhaas S, Jacobs AH, Wiek C, Roellecke K, Hanenberg H, Hartmann W, Wiendl H, Pankratz S, Meltzer J, Farwick N, Greune L, Fluegge M, Rossig C. Targeting Ewing sarcoma with activated and GD2specific chimeric antigen receptor-engineered human NK cells induces upregulation of immune-inhibitory HLA-G. OncoImmunology 2017; 6(1): e1250050

35. Hu Y, Tian ZG, Zhang C. Chimeric antigen receptor (CAR)transduced natural killer cells in tumor immunotherapy. Acta Pharmacol Sin 2018; 39(2): 167-176

36. Xu-Monette ZY, Zhang M, Li J, Young KH. PD-1/PD-L1 blockade: have we found the key to unleash the antitumor immune response? Front Immunol 2017; 8: 1597

37. Bengsch F, Knoblock DM, Liu A, McAllister F, Beatty GL. CTLA-4/CD80 pathway regulates T cell infiltration into pancreatic cancer. Cancer Immunol Immunother 2017; 66(12): 1609-1617

38. Li Y, Li D, Du M. TIM-3: a crucial regulator of NK cells in pregnancy. Cell Mol Immunol 2017; 14:948-950

39. Felices M, Miller JS. Targeting KIR blockade in multiple myeloma: trouble in checkpoint paradise? Clin Cancer Res 2016; 22(21): 5161-5163

40. Guillerey C, Huntington ND, Smyth MJ. Targeting natural killer cells in cancer immunotherapy. Nat Immunol 2016; 17(9): 10251036

41. McWilliams EM, Mele JM, Cheney C, Timmerman EA, Fiazuddin F, Strattan EJ, Mo X, Byrd JC, Muthusamy N, Awan FT. Therapeutic CD94/NKG2A blockade improves natural killer cell dysfunction in chronic lymphocytic leukemia. OncoImmunology 2016; 5(10): e1226720

42. Gallois A, Silva I, Osman I, Bhardwaj N. Reversal of natural killer cell exhaustion by TIM-3 blockade. OncoImmunology 2015; 3 (12): e946365

43. Vego H, Sand KL, Høglund RA, Fallang LE, Gundersen G, Holmøy T, Maghazachi AA. Monomethyl fumarate augments NK cell lysis of tumor cells through degranulation and the upregulation of NKp46 and CD107a. Cell Mol Immunol 2016; 13(1): 57-64

44. Floros T, Tarhini AA. Anticancer cytokines: biology and clinical effects of interferon- $\alpha 2$, interleukin (IL)-2, IL-15, IL-21, and IL12. Semin Oncol 2015; 42(4): 539-548

45. Nielsen CM, Wolf AS, Goodier MR, Riley EM. Synergy between common $\gamma$ chain family cytokines and IL-18 potentiates innate and adaptive pathways of NK cell activation. Front Immunol 2016; 7: 101

46. Srivastava S, Pelloso D, Feng H, Voiles L, Lewis D, Haskova Z, Whitacre M, Trulli S, Chen YJ, Toso J, Jonak ZL, Chang HC, 
Robertson MJ. Effects of interleukin-18 on natural killer cells: costimulation of activation through $\mathrm{Fc}$ receptors for immunoglobulin. Cancer Immunol Immunother 2013; 62(6): 1073-1082

47. Terme M, Ullrich E, Aymeric L, Meinhardt K, Coudert JD, Desbois M, Ghiringhelli F, Viaud S, Ryffel B, Yagita H, Chen L, Mécheri S, Kaplanski G, Prévost-Blondel A, Kato M, Schultze JL, Tartour E, Kroemer G, Degli-Esposti M, Chaput N, Zitvogel L. Cancerinduced immunosuppression: IL-18-elicited immunoablative NK cells. Cancer Res 2012; 72(11): 2757-2767

48. Wu D, Wu P, Qiu F, Wei Q, Huang J. Human $\gamma \delta T$-cell subsets and their involvement in tumor immunity. Cell Mol Immunol 2017; 14 (3): 245-253

49. Pittari G, Filippini P, Gentilcore G, Grivel JC, Rutella S. Revving up natural killer cells and cytokine-induced killer cells against hematological malignancies. Front Immunol 2015; 6: 230

50. Liu J, Cao X. Cellular and molecular regulation of innate inflammatory responses. Cell Mol Immunol 2016; 13(6): 711-721

51. Mittica G, Capellero S, Genta S, Cagnazzo C, Aglietta M, Sangiolo D, Valabrega G. Adoptive immunotherapy against ovarian cancer. J Ovarian Res 2016; 9(1): 30

52. Martín-Antonio B, Suñe G, Perez-Amill L, Castella M, UrbanoIspizua A. Natural killer cells: angels and devils for immunotherapy. Int J Mol Sci 2017; 18(9): E1868

53. Fang F, Xiao W, Tian Z. NK cell-based immunotherapy for cancer. Semin Immunol 2017; 31: 37-54

54. Veluchamy JP, Kok N, van der Vliet HJ, Verheul HMW, de Gruijl TD, Spanholtz J. The rise of allogeneic natural killer cells as a platform for cancer immunotherapy: recent innovations and future developments. Front Immunol 2017; 8: 631

55. Bachanova V, Burns LJ, McKenna DH, Curtsinger J, PanoskaltsisMortari A, Lindgren BR, Cooley S, Weisdorf D, Miller JS. Allogeneic natural killer cells for refractory lymphoma. Cancer Immunol Immunother 2010; 59(11): 1739-1744

56. Hofer E, Koehl U. Natural Killer cell-based cancer immunotherapies: from immune evasion to promising targeted cellular therapies. Front Immunol 2017; 8: 745

57. Pegram HJ, Haynes NM, Smyth MJ, Kershaw MH, Darcy PK. Characterizing the anti-tumor function of adoptively transferred NK cells in vivo. Cancer Immunol Immunother 2010; 59(8): 12351246

58. Romee R, Rosario M, Berrien-Elliott MM, Wagner JA, Jewell BA, Schappe T, Leong JW, Abdel-Latif S, Schneider SE, Willey S, Neal CC, Yu L, Oh ST, Lee YS, Mulder A, Claas F, Cooper MA, Fehniger TA. Cytokine-induced memory-like natural killer cells exhibit enhanced responses against myeloid leukemia. Sci Transl Med 2016; 8(357): 357ra123

59. Knorr DA, Bachanova V, Verneris MR, Miller JS. Clinical utility of natural killer cells in cancer therapy and transplantation. Semin Immunol 2014; 26(2): 161-172

60. Dahlberg CI, Sarhan D, Chrobok M, Duru AD, Alici E. Natural killer cell-based therapies targeting cancer: possible strategies to gain and sustain anti-tumor activity. Front Immunol 2015; 6: 605

61. Cheng M, Chen Y, Xiao W, Sun R, Tian Z. NK cell-based immunotherapy for malignant diseases. Cell Mol Immunol 2013; 10(3): 230-252

62. Dolstra H, Roeven MWH, Spanholtz J, Hangalapura BN, Tordoir M, Maas F, Leenders M, Bohme F, Kok N, Trilsbeek C,
Paardekooper J, van der Waart AB, Westerweel PE, Snijders TJF, Cornelissen JJ, Bos GMJ, Pruijt HFM, De Graaf AO, van der Reijden B, Jansen JH, van der Meer A, Huls G, Cany J, Preijers F, Blijlevens NMA, Schaap NM. Successful transfer of umbilical cord blood $\mathrm{CD}_{3} 4^{+}$hematopoietic stem and progenitor-derived NK cells in older acute myeloid leukemia patients. Clin Cancer Res 2017; 23(15):4107-4118

63. Rubnitz JE, Inaba H, Ribeiro RC, Pounds S, Rooney B, Bell T, Pui $\mathrm{CH}$, Leung W. NKAML: a pilot study to determine the safety and feasibility of haploidentical natural killer cell transplantation in childhood acute myeloid leukemia. J Clin Oncol 2010; 28(6): 955959

64. Curti A, Ruggeri L, D'Addio A, Bontadini A, Dan E, Motta MR, Trabanelli S, Giudice V, Urbani E, Martinelli G, Paolini S, Fruet F, Isidori A, Parisi S, Bandini G, Baccarani M, Velardi A, Lemoli RM. Successful transfer of alloreactive haploidentical KIR ligandmismatched natural killer cells after infusion in elderly high risk acute myeloid leukemia patients. Blood 2011; 118(12): 3273-3279

65. Klingemann H, Grodman C, Cutler E, Duque M, Kadidlo D, Klein AK, Sprague KA, Miller KB, Comenzo RL, Kewalramani T, Yu N, Van Etten RA, McKenna DH. Autologous stem cell transplant recipients tolerate haploidentical related-donor natural killer cellenriched infusions. Transfusion 2013; 53(2): 412-418, quiz 411

66. Kottaridis PD, North J, Tsirogianni M, Marden C, Samuel ER, Jide-Banwo S, Grace S, Lowdell MW. Two-stage priming of allogeneic natural killer cells for the treatment of patients with acute myeloid leukemia: a phase I trial. PLoS One 2015; 10(6): e0123416

67. Bachanova V, Cooley S, Defor TE, Verneris MR, Zhang B, McKenna DH, Curtsinger J, Panoskaltsis-Mortari A, Lewis D, Hippen K, McGlave P, Weisdorf DJ, Blazar BR, Miller JS. Clearance of acute myeloid leukemia by haploidentical natural killer cells is improved using IL-2 diphtheria toxin fusion protein. Blood 2014; 123(25): 3855-3863

68. Ciurea SO, Schafer JR, Bassett R, Denman CJ, Cao K, Willis D, Rondon G, Chen J, Soebbing D, Kaur I, Gulbis A, Ahmed S, Rezvani K, Shpall EJ, Lee DA, Champlin RE. Phase 1 clinical trial using mbIL21 ex vivo-expanded donor-derived NK cells after haploidentical transplantation. Blood 2017; 130(16): 1857-1868

69. Choi I, Yoon SR, Park SY, Kim H, Jung SJ, Jang YJ, Kang M, Yeom YI, Lee JL, Kim DY, Lee YS, Kang YA, Jeon M, Seol M, Lee JH, Lee JH, Kim HJ, Yun SC, Lee KH. Donor-derived natural killer cells infused after human leukocyte antigen-haploidentical hematopoietic cell transplantation: a dose-escalation study. Biol Blood Marrow Transplant 2014; 20(5): 696-704

70. Killig M, Friedrichs B, Meisig J, Gentilini C, Blüthgen N, Loddenkemper C, Labopin M, Basara N, Pfrepper C, Niederwieser DW, Uharek L, Romagnani C. Tracking in vivo dynamics of NK cells transferred in patients undergoing stem cell transplantation. Eur J Immunol 2014; 44(9): 2822-2834

71. Shah N, Li L, McCarty J, Kaur I, Yvon E, Shaim H, Muftuoglu M, Liu E, Orlowski RZ, Cooper L, Lee D, Parmar S, Cao K, Sobieiski C, Saliba R, Hosing C, Ahmed S, Nieto Y, Bashir Q, Patel K, Bollard C, Qazilbash M, Champlin R, Rezvani K, Shpall EJ. Phase I study of cord blood-derived natural killer cells combined with autologous stem cell transplantation in multiple myeloma. Br J Haematol 2017; 177(3): 457-466 
72. Passweg JR, Tichelli A, Meyer-Monard S, Heim D, Stern M, Kühne T, Favre G, Gratwohl A. Purified donor NK-lymphocyte infusion to consolidate engraftment after haploidentical stem cell transplantation. Leukemia 2004; 18(11): 1835-1838

73. Yoon SR, Lee YS, Yang SH, Ahn KH, Lee JH, Lee JH, Kim DY, Kang YA, Jeon M, Seol M, Ryu SG, Chung JW, Choi I, Lee KH. Generation of donor natural killer cells from CD34(+) progenitor cells and subsequent infusion after HLA-mismatched allogeneic hematopoietic cell transplantation: a feasibility study. Bone Marrow Transplant 2010; 45(6): 1038-1046

74. Rizzieri DA, Storms R, Chen DF, Long G, Yang Y, Nikcevich DA, Gasparetto C, Horwitz M, Chute J, Sullivan K, Hennig T, Misra D, Apple C, Baker M, Morris A, Green PG, Hasselblad V, Chao NJ. Natural killer cell-enriched donor lymphocyte infusions from A 36/6 HLA matched family member following nonmyeloablative allogeneic stem cell transplantation. Biol Blood Marrow Transplant 2010; 16(8): 1107-1114

75. Schmeel LC, Schmeel FC, Coch C, Schmidt-Wolf IG. Cytokineinduced killer (CIK) cells in cancer immunotherapy: report of the international registry on CIK cells (IRCC). J Cancer Res Clin Oncol 2015; 141(5): 839-849

76. Hölsken O, Miller M, Cerwenka A. Exploiting natural killer cells for therapy of melanoma. J Dtsch Dermatol Ges 2015; 13(1): 23 29

77. Braumüller $\mathrm{H}$, Wieder $\mathrm{T}$, Brenner E, Aßmann S, Hahn M, Alkhaled M, Schilbach K, Essmann F, Kneilling M, Griessinger C, Ranta F, Ullrich S, Mocikat R, Braungart K, Mehra T, Fehrenbacher B, Berdel J, Niessner H, Meier F, van den Broek M, Häring HU, Handgretinger R, Quintanilla-Martinez L, Fend F, Pesic M, Bauer J, Zender L, Schaller M, Schulze-Osthoff K, Röcken M. T-helper-1-cell cytokines drive cancer into senescence. Nature 2013; 494(7437): 361-365

78. Geller MA, Cooley S, Judson PL, Ghebre R, Carson LF, Argenta PA, Jonson AL, Panoskaltsis-Mortari A, Curtsinger J, McKenna D, Dusenbery K, Bliss R, Downs LS, Miller JS. A phase II study of allogeneic natural killer cell therapy to treat patients with recurrent ovarian and breast cancer. Cytotherapy 2011; 13(1): 98-107

79. Iliopoulou EG, Kountourakis P, Karamouzis MV, Doufexis D, Ardavanis A, Baxevanis CN, Rigatos G, Papamichail M, Perez SA. A phase I trial of adoptive transfer of allogeneic natural killer cells in patients with advanced non-small cell lung cancer. Cancer Immunol Immunother 2010; 59(12): 1781-1789

80. Yang Y, Lim O, Kim TM, Ahn YO, Choi H, Chung H, Min B, Her JH, Cho SY, Keam B, Lee SH, Kim DW, Hwang YK, Heo DS. Phase I study of random healthy donor-derived allogeneic natural killer cell therapy in patients with malignant lymphoma or advanced solid tumors. Cancer Immunol Res 2016; 4(3): 215-224

81. Tonn T, Schwabe D, Klingemann HG, Becker S, Esser R, Koehl U, Suttorp M, Seifried E, Ottmann OG, Bug G. Treatment of patients with advanced cancer with the natural killer cell line NK-92. Cytotherapy 2013; 15(12): 1563-1570

82. Miller JS, Soignier Y, Panoskaltsis-Mortari A, McNearney SA, Yun GH, Fautsch SK, McKenna D, Le C, Defor TE, Burns LJ, Orchard PJ, Blazar BR, Wagner JE, Slungaard A, Weisdorf DJ, Okazaki IJ, McGlave PB. Successful adoptive transfer and in vivo expansion of human haploidentical NK cells in patients with cancer. Blood 2005; 105(8): 3051-3057
83. Sadozai H, Gruber T, Hunger RE, Schenk M. Recent successes and future directions in immunotherapy of cutaneous melanoma. Front Immunol 2017; 8: 1617

84. Overacre-Delgoffe AE, Chikina M, Dadey RE, Yano H, Brunazzi EA, Shayan G, Horne W, Moskovitz JM, Kolls JK, Sander C, Shuai Y, Normolle DP, Kirkwood JM, Ferris RL, Delgoffe GM, Bruno TC, Workman CJ, Vignali DAA. Interferon- $\gamma$ drives $T_{\text {reg }}$ fragility to promote anti-tumor immunity. Cell 2017; 169(6): 11301141.e11

85. Tallerico R, Garofalo C, Carbone E. A new biological feature of natural killer cells: the recognition of solid tumor-derived cancer stem cells. Front Immunol 2016; 7: 179

86. Langers I, Renoux VM, Thiry M, Delvenne P, Jacobs N. Natural killer cells: role in local tumor growth and metastasis. Biologics 2012; 6: 73-82

87. Krasnova Y, Putz EM, Smyth MJ, Souza-Fonseca-Guimaraes F. Bench to bedside: NK cells and control of metastasis. Clin Immunol 2017; 177: 50-59

88. Ames E, Canter RJ, Grossenbacher SK, Mac S, Smith RC, Monjazeb AM, Chen M, Murphy WJ. Enhanced targeting of stemlike solid tumor cells with radiation and natural killer cells. OncoImmunology 2015; 4(9): e1036212

89. Specht HM, Ahrens N, Blankenstein C, Duell T, Fietkau R, Gaipl US, Günther C, Gunther S, Habl G, Hautmann H, Hautmann M, Huber RM, Molls M, Offner R, Rödel C, Rödel F, Schütz M, Combs SE, Multhoff G. Heat shock protein 70 (Hsp70) peptide activated natural killer (NK) cells for the treatment of patients with non-small cell lung cancer (NSCLC) after radiochemotherapy (RCTx) - from preclinical studies to a clinical phase II trial. Front Immunol 2015; 6: 162

90. Suck G, Linn YC, Tonn T. Natural killer cells for therapy of leukemia. Transfus Med Hemother 2016; 43(2): 89-95

91. Li L, Li W, Wang C, Yan X, Wang Y, Niu C, Zhang X, Li M, Tian H, Yao C, Jin H, Han F, Xu D, Han W, Li D, Cui J. Adoptive transfer of natural killer cells in combination with chemotherapy improves outcomes of patients with locally advanced colon carcinoma. Cytotherapy 2018; 20(1): 134-148

92. Fine JH, Chen P, Mesci A, Allan DSJ, Gasser S, Raulet DH, Carlyle JR. Chemotherapy-induced genotoxic stress promotes sensitivity to natural killer cell cytotoxicity by enabling missingself recognition. Cancer Res 2010; 70(18): 7102-7113

93. Dudley ME, Wunderlich JR, Yang JC, Sherry RM, Topalian SL, Restifo NP, Royal RE, Kammula U, White DE, Mavroukakis SA, Rogers LJ, Gracia GJ, Jones SA, Mangiameli DP, Pelletier MM, Gea-Banacloche J, Robinson MR, Berman DM, Filie AC, Abati A, Rosenberg SA. Adoptive cell transfer therapy following nonmyeloablative but lymphodepleting chemotherapy for the treatment of patients with refractory metastatic melanoma. J Clin Oncol 2005; 23(10): 2346-2357

94. Federico SM, McCarville MB, Shulkin BL, Sondel PM, Hank JA, Hutson P, Meagher M, Shafer A, Ng CY, Leung W, Janssen WE, Wu J, Mao S, Brennan RC, Santana VM, Pappo AS, Furman WL. A pilot trial of humanized anti-GD2 monoclonal antibody (hu14.18K322A) with chemotherapy and natural killer cells in children with recurrent/refractory neuroblastoma. Clin Cancer Res 2017; 23(21): 6441-6449

95. Benson DM Jr, Hofmeister CC, Padmanabhan S, Suvannasankha 
A, Jagannath S, Abonour R, Bakan C, Andre P, Efebera Y, Tiollier J, Caligiuri MA, Farag SS. A phase 1 trial of the anti-KIR antibody IPH2101 in patients with relapsed/refractory multiple myeloma. Blood 2012; 120(22): 4324-4333

96. Sanmamed MF, Pastor F, Rodriguez A, Perez-Gracia JL, Rodriguez-Ruiz ME, Jure-Kunkel M, Melero I. Agonists of costimulation in cancer immunotherapy directed against CD137, OX40, GITR, CD27, CD28, and ICOS. Semin Oncol 2015; 42(4): 640-655

97. Anderson AC, Joller N, Kuchroo VK. Lag-3, Tim-3, and TIGIT: co-inhibitory receptors with specialized functions in immune regulation. Immunity 2016; 44(5): 989-1004

98. Vallera DA, Felice M, McElmurry R, McCullar V, Zhou X, Schmohl JU, Zhang B, Lenvik AJ, Panoskaltsis-Mortari A, Verneris MR, Tolar J, Cooley S, Weisdorf DJ, Blazar BR, Miller JS. IL15 Trispecific killer engagers (TriKE) make natural killer cells specific to $\mathrm{CD} 33^{+}$targets while also inducing persistence, in vivo expansion, and enhanced function. Clin Cancer Res 2016; 22 (14):3440-3450

99. Chen S, Li J, Li Q, Wang Z. Bispecific antibodies in cancer immunotherapy. Hum Vaccin Immunother 2016; 12(10): 24912500

100. Liu D, Tian S, Zhang K, Xiong W, Lubaki NM, Chen Z, Han W. Chimeric antigen receptor (CAR)-modified natural killer cellbased immunotherapy and immunological synapse formation in cancer and HIV. Protein Cell 2017; 8(12): 861-877

101. Carlsten M, Childs RW. Genetic manipulation of NK cells for cancer immunotherapy: techniques and clinical implications. Front Immunol 2015; 6: 266

102. Sutlu T, Nyström S, Gilljam M, Stellan B, Applequist SE, Alici E. Inhibition of intracellular antiviral defense mechanisms augments lentiviral transduction of human natural killer cells: implications for gene therapy. Hum Gene Ther 2012; 23(10): 1090-1100

103. Boyiadzis M, Agha M, Redner RL, Sehgal A, Im A, Hou JZ, Farah R, Dorritie KA, Raptis A, Lim SH, Wang H, Lapteva N, Mei Z, Butterfield LH, Rooney CM, Whiteside TL. Phase 1 clinical trial of adoptive immunotherapy using "off-the-shelf" activated natural killer cells in patients with refractory and relapsed acute myeloid leukemia. Cytotherapy 2017; 19(10): 1225-1232

104. Ayello J, Hochberg J, Flower A, Chu Y, Baxi LV, Quish W, van de Ven C, Cairo MS. Genetically re-engineered K562 cells significantly expand and functionally activate cord blood natural killer cells: potential for adoptive cellular immunotherapy. Exp Hematol 2017; 46: 38-47

105. Shah N, Martin-Antonio B, Yang H, Ku S, Lee DA, Cooper LJ, Decker WK, Li S, Robinson SN, Sekine T, Parmar S, Gribben J, Wang M, Rezvani K, Yvon E, Najjar A, Burks J, Kaur I, Champlin RE, Bollard CM, Shpall EJ. Antigen presenting cell-mediated expansion of human umbilical cord blood yields log-scale expansion of natural killer cells with anti-myeloma activity. PLoS One 2013; 8(10): e76781

106. Cany J, van der Waart AB, Tordoir M, Franssen GM, Hangalapura BN, de Vries J, Boerman O, Schaap N, van der Voort R, Spanholtz J, Dolstra H. Natural killer cells generated from cord blood hematopoietic progenitor cells efficiently target bone marrowresiding human leukemia cells in NOD/SCID/IL2Rg(null) mice. PLoS One 2013; 8(6): e64384
107. Knorr DA, Ni Z, Hermanson D, Hexum MK, Bendzick L, Cooper LJN, Lee DA, Kaufman DS. Clinical-scale derivation of natural killer cells from human pluripotent stem cells for cancer therapy. Stem Cells Transl Med 2013; 2(4): 274-283

108. Hermanson DL, Bendzick L, Pribyl L, McCullar V, Vogel RI, Miller JS, Geller MA, Kaufman DS. Induced pluripotent stem cellderived natural killer cells for treatment of ovarian cancer. Stem Cells 2016; 34(1): 93-101

109. Veluchamy JP, Heeren AM, Spanholtz J, van Eendenburg JDH, Heideman DAM, Kenter GG, Verheul HM, van der Vliet HJ, Jordanova ES, de Gruijl TD. High-efficiency lysis of cervical cancer by allogeneic NK cells derived from umbilical cord progenitors is independent of HLA status. Cancer Immunol Immunother 2017; 66(1): 51-61

110. Spanholtz J, Preijers F, Tordoir M, Trilsbeek C, Paardekooper J, de Witte T, Schaap N, Dolstra H. Clinical-grade generation of active NK cells from cord blood hematopoietic progenitor cells for immunotherapy using a closed-system culture process. PLoS One 2011; 6(6): e20740

111. Tanaka J, Sugita J, Shiratori S, Shigematu A, Asanuma S, Fujimoto K, Nishio M, Kondo T, Imamura M. Expansion of NK cells from cord blood with antileukemic activity using GMP-compliant substances without feeder cells. Leukemia 2012; 26(5): 1149-1152

112. Boerman GH, van Ostaijen-ten Dam MM, Kraal KCJM, Santos SJ, Ball LM, Lankester AC, Schilham MW, Egeler RM, van Tol MJD. Role of NKG2D, DNAM-1 and natural cytotoxicity receptors in cytotoxicity toward rhabdomyosarcoma cell lines mediated by resting and IL-15-activated human natural killer cells. Cancer Immunol Immunother 2015; 64(5): 573-583

113. van Ostaijen-ten Dam MM, Prins HJ, Boerman GH, Vervat C, Pende D, Putter H, Lankester A, van Tol MJD, Zwaginga JJ, Schilham MW. Preparation of cytokine-activated NK cells for use in adoptive cell therapy in cancer patients: protocol optimization and therapeutic potential. J Immunother 2016; 39(2): 90-100

114. Wendt K, Wilk E, Buyny S, Schmidt RE, Jacobs R. Interleukin-21 differentially affects human natural killer cell subsets. Immunology 2007; 122(4): 486-495

115. Koehl U, Sörensen J, Esser R, Zimmermann S, Grüttner HP, Tonn T, Seidl C, Seifried E, Klingebiel T, Schwabe D. IL-2 activated NK cell immunotherapy of three children after haploidentical stem cell transplantation. Blood Cells Mol Dis 2004; 33(3): 261-266

116. Torelli GF, Rozera C, Santodonato L, Peragine N, D'agostino G, Montefiore E, Napolitano MR, Monque DM, Carlei D, Mariglia P, Pauselli S, Gozzer M, Bafti MS, Girelli G, Guarini A, Belardelli F, Foà R. A good manufacturing practice method to ex vivo expand natural killer cells for clinical use. Blood Transfus 2015; 13(3): 464-471

117. Granzin M, Stojanovic A, Miller M, Childs R, Huppert V, Cerwenka A. Highly efficient IL-21 and feeder cell-driven ex vivo expansion of human NK cells with therapeutic activity in a xenograft mouse model of melanoma. OncoImmunology 2016; 5 (9): e1219007

118. Kim EK, Ahn YO, Kim S, Kim TM, Keam B, Heo DS. Ex vivo activation and expansion of natural killer cells from patients with advanced cancer with feeder cells from healthy volunteers. Cytotherapy 2013; 15(2): 231-241.e1

119. Zhang H, Cui Y, Voong N, Sabatino M, Stroncek DF, Morisot S, 
Civin CI, Wayne AS, Levine BL, Mackall CL. Activating signals dominate inhibitory signals in CD137L/IL-15 activated natural killer cells. J Immunother 2011; 34(2): 187-195

120. Childs RW, Berg M. Bringing natural killer cells to the clinic: $e x$ vivo manipulation. Hematology Am Soc Hematol Educ Program 2013; 2013: 234-246

121. Oyer JL, Igarashi RY, Kulikowski AR, Colosimo DA, Solh MM, Zakari A, Khaled YA, Altomare DA, Copik AJ. Generation of highly cytotoxic natural killer cells for treatment of acute myelogenous leukemia using a feeder-free, particle-based approach. Biol Blood Marrow Transplant 2015; 21(4): 632-639

122. Sakamoto N, Ishikawa T, Kokura S, Okayama T, Oka K, Ideno M, Sakai F, Kato A, Tanabe M, Enoki T, Mineno J, Naito Y, Itoh Y, Yoshikawa T. Phase I clinical trial of autologous NK cell therapy using novel expansion method in patients with advanced digestive cancer. J Transl Med 2015; 13(1): 277

123. Lapteva N, Durett AG, Sun J, Rollins LA, Huye LL, Fang J, Dandekar V, Mei Z, Jackson K, Vera J, Ando J, Ngo MC, CoustanSmith E, Campana D, Szmania S, Garg T, Moreno-Bost A, Vanrhee F, Gee AP, Rooney CM. Large-scale ex vivo expansion and characterization of natural killer cells for clinical applications. Cytotherapy 2012; 14(9): 1131-1143

124. Williams BA, Law AD, Routy B, denHollander N, Gupta V, Wang $\mathrm{XH}$, Chaboureau A, Viswanathan S, Keating A. A phase I trial of NK-92 cells for refractory hematological malignancies relapsing after autologous hematopoietic cell transplantation shows safety and evidence of efficacy. Oncotarget 2017; 8(51): $89256-$ 89268

125. Arai S, Meagher R, Swearingen M, Myint H, Rich E, Martinson J, Klingemann $H$. Infusion of the allogeneic cell line NK-92 in patients with advanced renal cell cancer or melanoma: a phase I trial. Cytotherapy 2008; 10(6): 625-632

126. Shah N, Li L, McCarty J, Kaur I, Yvon E, Shaim H, Muftuoglu M, Liu E, Orlowski RZ, Cooper L, Lee D, Parmar S, Cao K, Sobieiski C, Saliba R, Hosing C, Ahmed S, Nieto Y, Bashir Q, Patel K,
Bollard C, Qazilbash M, Champlin R, Rezvani K, Shpall EJ. Phase I study of cord blood-derived natural killer cells combined with autologous stem cell transplantation in multiple myeloma. Br J Haematol 2017; 177(3): 457-466

127. Parkhurst MR, Riley JP, Dudley ME, Rosenberg SA. Adoptive transfer of autologous natural killer cells leads to high levels of circulating natural killer cells but does not mediate tumor regression. Clin Cancer Res 2011; 17(19): 6287-6297

128. Liang S, Xu K, Niu L, Wang X, Liang Y, Zhang M, Chen J, Lin M. Comparison of autogeneic and allogeneic natural killer cells immunotherapy on the clinical outcome of recurrent breast cancer. Onco Targets Ther 2017; 10: 4273-4281

129. Leivas A, Perez-Martinez A, Blanchard MJ, Martín-Clavero E, Fernández L, Lahuerta JJ, Martinez-Lopez J. Novel treatment strategy with autologous activated and expanded natural killer cells plus anti-myeloma drugs for multiple myeloma. OncoImmunology 2016; 5(12): e1250051

130. Szmania S, Lapteva N, Garg T, Greenway A, Lingo J, Nair B, Stone K, Woods E, Khan J, Stivers J, Panozzo S, Campana D, Bellamy WT, Robbins M, Epstein J, Yaccoby S, Waheed S, Gee A, Cottler-Fox M, Rooney C, Barlogie B, van Rhee F. Ex vivoexpanded natural killer cells demonstrate robust proliferation in vivo in high-risk relapsed multiple myeloma patients. J Immunother 2015; 38(1): 24-36

131. Pérez-Martínez A, Fernández L, Valentín J, Martínez-Romera I, Corral MD, Ramírez M, Abad L, Santamaría S, González-Vicent M, Sirvent S, Sevilla J, Vicario JL, de Prada I, Diaz MA. A phase I/ II trial of interleukin-15-stimulated natural killer cell infusion after haplo-identical stem cell transplantation for pediatric refractory solid tumors. Cytotherapy 2015; 17(11): 1594-1603

132. Shaffer BC, Le Luduec JB, Forlenza C, Jakubowski AA, Perales MA, Young JW, Hsu KC. Phase II study of haploidentical natural killer cell infusion for treatment of relapsed or persistent myeloid malignancies following allogeneic hematopoietic cell transplantation. Biol Blood Marrow Transplant 2016; 22(4): 705-709 